\title{
Replacement of Coarse Aggregate with Locally Available Brick Aggregate
}

\author{
Daddan Khan Bangwar \\ Department of Civil Engineering \\ Quaid-e-Awam University of \\ Engineering, Science \& Technology \\ Nawabshah, Sindh, Pakistan \\ daddan@quest.edu.pk
}

\author{
Abdullah Saand \\ Quaid-e-Awam University of \\ Engineering, Science \& Technology \\ Nawabshah, Sindh, Pakistan \\ abdullah@quest.edu.pk
}

\author{
Manthar Ali Keerio \\ Quaid-e-Awam University of \\ Engineering, Science \& Technology \\ Nawabshah, Sindh, Pakistan \\ mantharali99@quest.edu.pk
}

\author{
Mukhtiar Ali Soomro \\ Department of Civil Engineering \\ Quaid-e-Awam University of Engineering, \\ Science \& Technology \\ Nawabshah, Pakistan \\ eng.soomro@gmail.com
}

\author{
Abdul Nasir Laghari \\ Department of Energy and Environment Engineering, \\ Quaid-e-Awam University of Engineering, Science and \\ Technology \\ Nawabshah, Pakistan \\ Mashaalnasirlaghari@gmail.com
}

\begin{abstract}
Due to the abundant usage of concrete as a construction material, there is a fast dwindling source of aggregates. There are regions where there is scarcity of coarse aggregate, so to resolve this problem, Bricks Aggregates (BAs) can be used as coarse aggregate. A concrete mix ratio of $1: 2: 4$ having characteristics strength of 3000 psi has been used in this experimental work. Compressive and tensile strength of concrete mix where $50 \%$ coarse aggregate is replaced with brick aggregate and concrete mix where $100 \%$ coarse aggregate is replaced with brick aggregate and addition of silica fume as a supplementary cementing material have been evaluated at 7, 14 and 21 days of age. The experimental test results revealed the compressive and tensile strength of concrete where coarse aggregate is replaced at $50 \%$ is almost the same as that normal concrete at the 7, 14, 21 and 28 days.
\end{abstract}

Keywords-concrete; brick; aggregate; coarse; compressive; strength; tensile; silica fume

\section{INTRODUCTION}

The rigorous use of aggregates in constructions is a very vital environmental apprehension. In a county like Pakistan, the ease of use of aggregates becomes a severe problem. In order to decrease the exploit of natural aggregates from natural resources and for energy preservation, the use of recycled aggregates may be employed. Plentiful studies illustrate the possibility of recycling aggregates such as ceramics [1], rubber $[2,3]$, glass [4], and demolition wastes, i.e. bricks and concrete. Because of the high quantity of concrete from demolition wastes, this material was studied as substitution of natural aggregates by several researchers [5-8]. Nevertheless, these aggregates are highly porous, and contain a high amount of impurities [8,9]. Limited studies were conducted on the possibility of fresh concrete waste. These aggregates are mainly composed of over ordered fresh concrete. The benefit of this waste is that it contains limited quantity of impurities in contrast with other recycled aggregates. A concrete batching plant receives from numerous construction sites a huge amount of over ordered fresh concrete. Currently, the practice of managing over ordered fresh concrete is to use it in road or to dump it into landfill, which is deemed as a non-advantageous solution. Moreover, it will be of high cost in the close future because of the saturation of landfill areas [10]. Recycling this material is of particular consideration due to its use it can significantly trim down the problem of waste storage, and simultaneously it helps the conservation of natural aggregate resources. Recent successful studies on the use of fresh concrete waste as aggregates in concrete have been reported $[11,12]$. In this experimental study, concrete mixes with fine and coarse aggregates recycled from brick bates as a substitution of natural aggregate and addition of silica fume as a supplementary cementing material have been studied.

\section{EXPERIENTIAL PROCEDURE}

OPC was used throughout in this experimental work. The concrete ratio of 1:2:4 having designed strength of $3000 \mathrm{psi}$ and along with silica fume, coarse aggregate having maximum size of $25 \mathrm{~mm}$, brick aggregate having $25 \mathrm{~mm}$ and fine aggregate having maximum size of $4.75 \mathrm{~mm}$ were used. The compressive and tensile strength of concrete replacing coarse aggregate $50 \%$ by brick aggregate and concrete mix where coarse aggregate is replaced by $100 \%$ brick aggregate and with the addition of silica fume (SF) as a supplementary cementing material at the ages of 7, 14, 21 and 28 days. A total of 120 specimens were prepared with mixes designed as shown in Table I. 


\section{RESULTS AND DISCUSSION}

Figure 1 shows the mean compressive strength of the normal concrete, concrete replacing $50 \%$ coarse aggregate with brick aggregate (BA) and concrete replacing $100 \%$ coarse aggregate with (BA) with the addition of $10 \% \mathrm{SF}$. As shown in the figure, the concrete having $50 \% \mathrm{BA}$ is achieving almost the same strength as the specified strength of 1:2:4 concrete mix. However the strength of the concrete mix where coarse aggregate is replaced by $100 \%$ and with the addition of $10 \%$ silica fume reaches somewhat below the 28-characteristic strength of the concrete mix. This decrease in strength clearly points out the importance of aggregate in concrete in terms of strength irrespective of the addition of silica flume as a supplementary cementing material. Furthermore, the decrease in the strength may be due to the reason of more absorption capacity of brick aggregate and silica fume. The 28-days tensile strength of the concrete depicts same behavior as that of the compressive strength of the concrete mixes at the different ages.

TABLE I. MIX PROPORTION OF CONCRETE

\begin{tabular}{|c|c|c|c|c|c|c|c|c|}
\hline S. No & Concrete Mix & $\mathbf{C e m e n t}$ & $\begin{array}{c}\mathbf{S . F} \\
\left(\mathbf{K g} / \mathbf{m}^{3}\right)\end{array}$ & $\begin{array}{c}\text { Water } \\
\left(\mathbf{K g} / \mathbf{m}^{3}\right)\end{array}$ & $\begin{array}{c}\mathbf{F . A} \\
\left(\mathbf{K g} / \mathbf{m}^{3}\right)\end{array}$ & $\begin{array}{c}\mathbf{B . A} \\
\left(\mathbf{K g} / \mathbf{m}^{3}\right)\end{array}$ & $\begin{array}{c}\mathbf{C . A} \\
\left(\mathbf{K g} / \mathbf{m}^{3}\right)\end{array}$ & $\begin{array}{c}\mathbf{S l u m p} \\
\left(\mathbf{K g} / \mathbf{m}^{3}\right)\end{array}$ \\
\hline $\mathbf{( m m})$
\end{tabular}

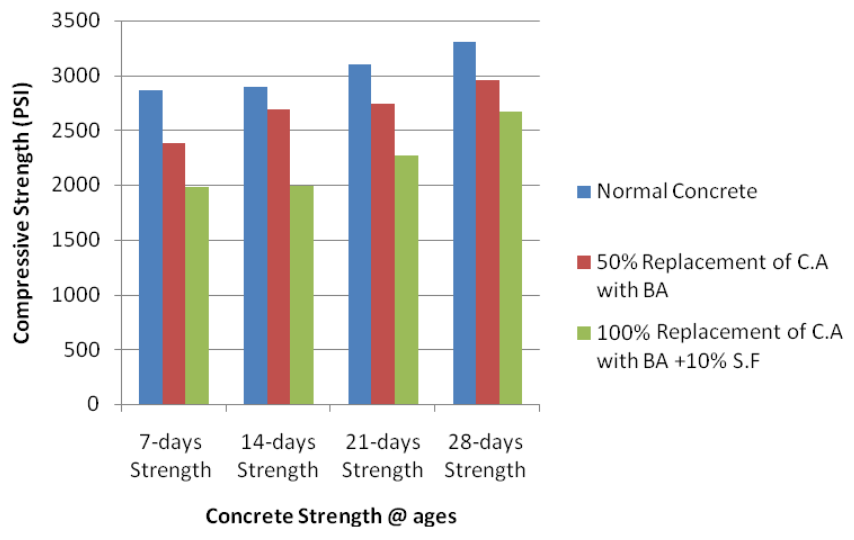

Fig. 1. Elemental composition of RHAs sample

\section{CONCLUSION}

In this study, the characteristics of concrete mixes with fine and coarse aggregates recycled from brick bates with the addition of silica fume as a supplementary cementing material have been studied. Results show that coarse aggregate could be replaced by brick aggregate up to $50 \%$ by weight in the production of normal use of concrete without any loss of strength and other basic properties of the concrete.

\section{ACKNOWLEDGEMENT}

The authors express their thanks to Civil Engineering Department QUEST Nawabshah for the necessary support.

\section{REFERENCES}

[1] A. R. Khaloo, "Properties of concrete using crushed clinker brick as coarse aggregate", ACI Materials Journal, Vol. 91, No. 2, pp. 401-407, 1994

[2] N. Segre, I. Joekes, "Use of tire rubber particles as addition to cement paste", Cement and Concrete Research, Vol. 30, No. 9, pp. 1421-1425, 2000

[3] A. Turatsinze, S. Bonnet, J.-L. Granju, "Mechanical characterisation of cement-based mortar incorporating rubber aggregates from recycled worn tyres", Building and Environment, Vol. 40, No. 2, pp. 221-226, 2005

[4] I. B. Topcu, M. Canbaz, "Properties of concrete containing waste glass", Cement and Concrete Research, Vol. 34, No. 2, pp. 267-274, 2004

[5] J. M. V. Gomez-Soberon, "Porosity of recycled concrete with substitution of recycled concrete aggregate: an experimental study", Cement and Concrete Research, Vol. 32, No. 8, pp. 1301-1311, 2002

[6] T.-Y. Tu, Y.-Y. Chen, C.-L. Hwang, "Properties of HPC with recycled aggregates", Cement and Concrete Research, Vol. 36, No. 5, pp. 943 950,2006

[7] S.-C. Kou, C.-S. Poon, M. Etxeberria, "Influence of recycled aggregates on long term mechanical properties and pore size distribution of concrete", Cement and Concrete Composites, Vol. 33, No. 2, pp. 286 291,2011

[8] R. Zaharieva, F. Buyle-Bodin, F. Skoczylas, E. Wirquin, "Assessment of the surface permeation properties of recycled aggregate concrete", Cement and Concrete Composites, Vol. 25, No. 2, pp. 223-232, 2003

[9] R. Boder, Substitution des granulats alluvionnaires dans l'industrie du béton par les granulats marins, concassés ou recyclés, CERIB, Epernon, France, 2003

[10] V. W. Y. Tam, C. M. Tam, "Economic comparison of recycling overordered fresh concrete: a case study approach", Resources, Conservation and Recycling, Vol. 52, No. 2, pp. 208-218, 2007

[11] S. L. Correia, F. L. Souza, G. Dienstmann, A. M. Segadaes, "Assessment of the recycling potential of fresh concrete waste using a factorial design of experiments", Waste Management, Vol. 29, No. 11, pp. 2886-2891, 2009

[12] S.-C. Kou, B.-J. Zhan, C.-S. Poon, "Feasibility study of using recycled fresh concrete waste as coarse aggregates in concrete", Construction and Building Materials, Vol. 28, No. 1, pp. 549-556, 2012 